Forthcoming, Journal of International Economics

\title{
Estimation of Cross-Country Differences in Industry Production Functions
}

\author{
James Harrigan \\ International Research Department, Federal Reserve Bank of New York*
}

JEL Classification Codes F1, D24, O47

Keywords: total factor productivity, scale economies

\begin{abstract}
$\underline{\text { Abstract }}$
International trade economists typically assume that there are no cross-country differences in industry total factor productivity (TFP). In contrast, this paper finds large and persistent TFP differences across a group of industrialized countries in the 1980s. The paper calculates TFP indices, and statistically examines the sources of the observed large TFP differences across countries. Two hypotheses are examined to account for TFP differences: constant returns to scale production with country-specific technological differences, and industry-level scale economies with identical technology in each country. The data support the constant returns/different technology hypothesis over the increasing returns/same technology hypothesis.
\end{abstract}

* 33 Liberty Street, New York, NY 10045. phone: (212) 720-8951, fax: (212) 720-6831, e-mail: james.harrigan@ny.frb.org. 


\section{Introduction}

Two fundamental assumptions in neoclassical trade theory are that technological knowledge is the same in all countries, and that production processes exhibit constant returns to scale. An equivalent way of stating this assumption is that total factor productivity (TFP) for each industry is the same in every country: a given level of inputs will produce the same amount of output in each country. If this is the case, then production sets differ across countries only because of differences in factor endowments. Recent work by Harrigan (1995), however, shows that there are systematic differences across countries in industry outputs that can not be explained by differences in factor endowments. While there are many possible explanations for this result, one such explanation is that technology is not the same across countries. This is a hypothesis which has gained greater attention from international economists recently, including Trefler (1993, 1995), Dollar and Wolff (1993) and Harrigan (1997a). If technology is not the same across countries, then much of the theoretical work in neoclassical trade theory is irrelevant to applied research on cross-country comparisons, and much of the applied research that assumes identical technology (for example, many applied general equilibrium models and factor endowment regressions) is misspecified.

One important possibility, however, is that TFP differences are the result of a mismatch between the theory of TFP comparisons and the technological and measurement processes which generate the data. For example, if there are increasing returns to scale at the level of national industries, then countries with larger industry outputs will have higher measured TFP even if technology is identical. If there is imperfect competition in output or input markets, then labor's share of total factor payments need not correspond to labor's share of total costs. If there is 
substantial measurement error in inputs and/or outputs, then TFP may also appear to be substantially different even if the underlying technology is the same. This paper investigates the possibility that returns to scale and/or imperfect competition effects bias TFP comparisons.

In this paper, I estimate cross-country technology differences using two approaches. I compute TFP indexes using a panel of data on value added, capital stocks, and employment for eleven OECD countries during the 1980's. This data set combines newly available data from the OECD and the U.S. Bureau of Economic Analysis. Using the same data, I directly estimate crosscountry differences in industry production functions. The econometric results are used to draw inferences about technological differences which are compared to the direct calculations of TFP .

There are two general types of studies that have calculated international TFP differentials: studies of value added and studies of gross output. Within this breakdown, there are studies which vary in their level of disaggregation and their country coverage. There are a number of studies of growth in TFP which are not reviewed here, since they are not directly relevant to the question of the level of TFP across countries ${ }^{1}$.

Among the studies which calculate TFP using a value added output measure are Dollar and Wolff (1993), Dollar, Wolff and Baumol (1988), Maskus (1991), van Ark (1993), and van Ark and Pilat (1993). The first three of these use overall GDP price levels to deflate sectoral outputs. This introduces a distortion to the extent that relative prices differ across countries, and Harrigan (1997b) shows that this distortion is large enough to substantively change the results of TFP comparisons. The two closely related studies by van Ark (1993) and van Ark and Pilat (1993) deflate value added by a price index which is constructed by direct comparisons of output prices at the wholesale level rather than using GDP price levels. Unfortunately, this theoretically 
superior procedure is compromised by the very small number of matches across countries for particular products (see the discussion by Jorgenson following van Ark and Pilat 1993). In addition, the van Ark (1993) and van Ark and Pilat (1993) studies include only a small number of countries and years.

The second class of studies of TFP uses data on gross output, and deflates all inputs (capital, labor, materials, energy, etc) in a symmetric way. This procedure was pioneered by Jorgenson and various coauthors, and is undoubtedly the most theoretically appealing and least restrictive method of making productivity comparisons (see Jorgenson (1990) for a comprehensive introduction to the methodology). Because of the very stringent data requirements needed for the Jorgenson procedure, however, there have been only two studies applying this method and they have compared only two countries, the United States and Japan.

The current paper extends the literature in three ways. First, to avoid assuming that relative prices do not vary across countries I construct estimates of sector-specific price levels. Second, I use data on a broad sample of OECD countries over ten years. Lastly, I use both index number theory and cross-country econometric analysis to characterize the extent of TFP differences $^{2}$.

\section{Data}

The data and measurement issues involved in making international comparisons of industries are discussed extensively in a companion paper to this one (Harrigan (1997b)). In this section I describe some of the methods and conclusions of that paper. 


\subsection{Real Output}

Cross-country comparisons require data on outputs, inputs and prices. The OECD has recently compiled data on nominal output, valued added, employment, and gross fixed capital formation (GFCF) from a number of existing data sources to form a single internally consistent source for disaggregated cross-country comparisons ${ }^{3}$.

Making the OECD data internationally comparable requires currency conversion, and this is the most problematic part of any international comparison. Using purchasing power parity (PPP) GDP deflators is the most common procedure, but this biases industry level comparisons since it implicitly assumes that there are no relative price differences across countries. Some of the problems of using GDP PPPs can be mitigated by using the component deflators reported in the OECD documentation of the construction of the overall GDP PPPs (Ward 1985, OECD 1987, and OECD 1992b). This paper constructs price levels for machinery and equipment using this disaggregated data ${ }^{4}$. Expressed as a percentage of the overall GDP deflator price levels, the constructed price levels vary widely across countries: the standard deviation across countries is on the order of 20 percentage points, with a range of around 65 percentage points (see Table 1 in Harrigan (1997b)). If a country's price level is high, it is because a standardized unit of output is more expensive in that country than in the US; it does not mean that output in that country is of higher quality, since the price index ostensibly compares like goods in the countries being compared. The standardized unit of output being compared is meant to be representative of the OECD as a whole, so the choice of the dollar as a standard for purposes of cross country comparisons is inconsequential. 
The above procedure converts nominal domestic currency magnitudes into units of nominal US dollars sufficient to purchase a standardized basket of goods. To make these dollar magnitudes comparable over time, value added is deflated using industry price indexes from the Bureau of Economic Analysis.

\subsection{Capital}

The OECD data reports industry investment flows in current own-currency values. I convert industry investment into U.S. dollars using the overall investment price levels from Summers and Heston (1991), and the flows are then converted into constant dollars using the implicit deflator for US fixed non-residential investment from the National Income and Product Accounts, various years.

Given the series on real investment, the capital stock is a function of past investment flows. The choice of function is both important and somewhat arbitrary, since it is not feasible to gather information on useful asset lives and depreciation patterns across industries and countries. I (rather uncomfortably) follow many previous researchers and construct the capital stock as a distributed lag of past investment flows:

$$
k_{c j t}=\sum_{n=1}^{T}(1-\delta)^{n-1} i_{c j, t-n}
$$

where $\mathrm{k}_{\mathrm{cjt}}$ is the capital stock of industry $\mathrm{j}$ in country $\mathrm{c}$ at the beginning of year $\mathrm{t}, \delta<1$ is the discount factor, and $\mathrm{i}$ is real investment during year $\mathrm{t}$. Note that the capital stock in year $\mathrm{t}$ does not include year t investment, but only up through year $t-1$. In this paper, because I only have investment going back to 1970 , I use $\delta=0.15$ and $\mathrm{T}=10$. If the actual useful life of a capital 
good is 20 years, this amounts to dropping about $10 \%$ of the total weight used in constructing the "true" capital stock.

An alternative method is to use the so-called delayed linear scrapping rule: a newly purchased capital good is added to the capital stock, and after a period of S years a constant proportion $1 /(\mathrm{M}+1)$ is scrapped each year:

$$
k_{c j t}=\sum_{n=1}^{S} i_{c j, t-n}+\sum_{n=S+1}^{S+M} i_{c j, t-n} \cdot\left[1-\frac{n-S}{M+1}\right]
$$

This is a formula used by many national statistical agencies, as well as by the OECD in it's Intersectoral Database for international comparisons (OECD, 1996). With $S=3$ and $M=7$, the resulting capital stock estimates are extremely highly correlated with the capital stocks constructed using equation (1): the minimum within-industry correlation is 0.9992 . Of course, there are other plausible parameter choices which would yield different capital stock estimates, but given the short sample available, all would be highly correlated since they would all give high weight to recent investments, quickly declining weight to investments more than a few years old, and zero weight to investments more than 10 years old.

\subsection{Labor}

Labor is derived from industry employment figures in the STAN data. Because employment is an imperfect indicator of labor input, two adjustments are made to these data. First, the employment data are converted into 40-hour work week equivalents using average 
hours worked in manufacturing. Second, the data are disaggregated into three occupational categories (professional/technical, managerial, and other) using the proportions of each occupation in manufacturing ${ }^{5}$. The occupational categories are aggregated into total labor 1 using a translog index:

$$
l=l_{1}^{\alpha_{1}} l_{2}^{\alpha_{2}} l_{3}^{\alpha_{3}}
$$

where the subscripts refer to the three occupational categories and country-industry-year subscripts are omitted for readability. The weights $\alpha_{1}, \alpha_{2}$, and $\alpha_{3}$ sum to unity and are constructed from each occupation's share in total labor cost. Analogously to the total cost shares used in the TFP index introduced below, I use the following weights in constructing the index of labor for country $\mathrm{c}$ in year t:

$$
\alpha_{\mathrm{m}}=\left(\mathrm{s}_{\mathrm{m}}+\overline{\mathrm{s}}_{\mathrm{m}}\right) / 2
$$

where $\mathrm{s}_{\mathrm{m}}$ is the share of occupation $\mathrm{m}$ in total cost for a particular country-industry-year observation and $\bar{s}_{\mathrm{m}}$ is the arithmetic mean of $\mathrm{s}_{\mathrm{m}}$ across observations. Construction of the labor cost shares $\mathrm{s}_{\mathrm{m}}$ requires data on wages. Unfortunately, internationally comparable wage data that is disaggregated by occupation is unavailable. The approach used here is to assume that the occupational wage differentials in the United States are the same as in other countries. These wage differentials can be constructed from data in the Bureau of Labor Statistics (BLS) Handbook of Labor Statistics for the years 1983 to 1988 (BLS 1989, page 163-168) ${ }^{6}$. Denote the wage of occupation $m$ as $w_{m}$ and the occupational wage differentials as $\beta_{m}$, with the normalization that the lowest paid occupation is occupation 1 and $\beta_{1}=1$. Substituting $\mathrm{w}_{\mathrm{m}}=\beta_{\mathrm{m}} \mathrm{w}_{1}$ into the definition of total labor cost $=\sum_{\mathrm{m}} \mathrm{w}_{\mathrm{m}} \cdot \mathrm{l}_{\mathrm{m}}$, and solving for $\mathrm{w}_{1}$ it is the case that 


$$
\mathrm{w}_{1}=\sum_{\mathrm{m}} \mathrm{w}_{\mathrm{m}} \cdot \mathrm{l}_{\mathrm{m}} / \sum_{\mathrm{m}} \beta_{\mathrm{m}} \cdot \mathrm{l}_{\mathrm{m}}
$$

Given this constructed numeraire wage, the wage shares follow immediately as

$$
\mathrm{s}_{\mathrm{m}}=\mathrm{w}_{\mathrm{m}} \mathrm{l}_{\mathrm{m}} / \sum_{\mathrm{j}} \mathrm{w}_{\mathrm{j}} \mathrm{l}_{\mathrm{j}}=\beta_{\mathrm{m}} \mathrm{l}_{\mathrm{m}} / \sum_{\mathrm{j}} \beta_{\mathrm{j}} \cdot \mathrm{l}_{\mathrm{j}} \quad \mathrm{m}=1, \ldots, \mathrm{L} .
$$

\section{Total Factor Productivity}

In this section I report relative TFP levels calculated from the above described data on value added $\mathrm{y}$, employment 1 , and capital stocks $\mathrm{k}$. The TFP calculations require that I assume constant returns to scale throughout this section. The comparison of TFP between two countries b and c asks the question: how much output could country b produce using country c's inputs, or vice versa? Assume that value added can be modeled as a function of the capital stock and employment, and that these inputs are measured perfectly and in the same units for each observation. For a particular industry in country $\mathrm{c}$, write real value added $\mathrm{y}_{\mathrm{c}}$ as a constant returns to scale function of the real capital stock $\mathrm{k}_{\mathrm{c}}$ and the level of employment $\mathrm{l}_{\mathrm{c}}$ :

$$
\mathrm{y}_{\mathrm{c}}=\mathrm{f}_{\mathrm{c}}\left(\mathrm{k}_{\mathrm{c}}, 1_{\mathrm{c}}\right)=\mathrm{f}_{\mathrm{c}}\left(\mathrm{x}_{\mathrm{c}}\right)
$$

Now define the distance function $\mathrm{D}_{\mathrm{b}}\left(\mathrm{y}_{\mathrm{c}}, \mathrm{x}_{\mathrm{c}}\right)$ as follows:

$$
\mathrm{D}_{\mathrm{b}}\left(\mathrm{y}_{\mathrm{c}}, \mathrm{x}_{\mathrm{c}}\right)=\operatorname{Min}_{\delta}\left\{\delta \in \mathbb{R}_{+}^{1}: \mathrm{f}_{\mathrm{b}}\left(\delta \mathrm{x}_{\mathrm{c}}\right) \geq \mathrm{y}_{\mathrm{c}}\right\}
$$

With this definition, $\mathrm{D}_{\mathrm{b}} \mathrm{x}_{\mathrm{c}}$ is the smallest input bundle capable of producing $\mathrm{y}_{\mathrm{c}}$ using the technology in country $b . D_{c}\left(y_{b}, x_{b}\right)$ is defined analogously. Note that in general it need not be the case that $D_{c}$ $=1 / \mathrm{D}_{\mathrm{b}}$, so that the calculated distance between the technologies of two countries $\mathrm{b}$ and $\mathrm{c}$ depends on the value added function used for the comparison. Further complications arise in making multilateral comparisons within a panel of countries since the choice of base country and year will affect the conclusions. As a solution to this index number problem, suppose that each country's 
value added function is translog with identical second-order terms, so that the value added function of country c can be written as

$$
\ln \mathrm{y}_{\mathrm{c}}=\alpha_{0 \mathrm{c}}+\alpha_{1 \mathrm{c}} \ln 1_{\mathrm{c}}+\alpha_{2 \mathrm{c}} \ln \mathrm{k}_{\mathrm{c}}+\alpha_{3}\left(\ln 1_{\mathrm{c}}\right)^{2}+\alpha_{4}\left(\ln \mathrm{k}_{\mathrm{c}}\right)^{2}+\alpha_{5}\left(\ln 1_{\mathrm{c}} \cdot \ln \mathrm{k}_{\mathrm{c}}\right)
$$

where constant returns to scale requires $\alpha_{1 \mathrm{c}}+\alpha_{2 \mathrm{c}}=1$ and $2 \alpha_{3}+\alpha_{5}=2 \alpha_{4}+\alpha_{5}=0$. Under the additional assumptions that producers are cost-minimizers and price takers in input markets, Caves, Christensen and Diewert (1982) show that the geometric mean of the two distance functions for any two countries $\mathrm{b}$ and $\mathrm{c}$ gives the TFP index

$$
\operatorname{TFP}_{c d}=\frac{y_{c}}{y_{d}}\left(\frac{\bar{l}}{l_{c}}\right)^{\sigma_{c}}\left(\frac{\bar{k}}{k_{c}}\right)^{1-\sigma_{c}}\left(\frac{l_{d}}{\bar{l}}\right)^{\sigma_{d}}\left(\frac{k_{d}}{\bar{k}}\right)^{1-\sigma_{d}}
$$

where a bar denotes an average over all the observations in the sample and $\sigma_{\mathrm{j}}=\left(\mathrm{s}_{\mathrm{j}}+\overline{\mathrm{s}}\right) / 2$, where $s_{j}$ is labor's share in total cost in observation $\mathrm{j}^{7}$. To interpret (3), notice that if the value added function is Cobb-Douglas, then the labor shares are constant and (3) reduces to the Cobb-Douglas index:

$$
T F P_{c d}=\frac{y_{c}}{y_{d}}\left(\frac{l_{d}}{l_{c}}\right)^{s}\left(\frac{k_{d}}{k_{c}}\right)^{1-s}
$$

The index (3) is superlative, meaning that it is exact for the flexible translog functional form $^{8}$. Furthermore, (3) is transitive:

$$
\mathrm{TFP}_{\mathrm{bd}}=\mathrm{TFP}_{\mathrm{bc}} \cdot \mathrm{TFP}_{\mathrm{cd}}
$$

which makes the choice of base country and year inconsequential ${ }^{9}$. 
A major difficulty in implementing a TFP comparison is volatility in the labor shares $\mathrm{s}_{\mathrm{j}}$, which is suggestive of measurement error. Under the assumptions about technology and input market behavior used to derive (3), labor's share in total cost is equal to the elasticity of output with respect to labor, so that

$$
\mathrm{s}_{\mathrm{c}}=\alpha_{1 \mathrm{c}}+\alpha_{5} \ln \left(\mathrm{k}_{\mathrm{c}} / \mathrm{l}_{\mathrm{c}}\right)
$$

The cost shares in the raw data are very volatile, and in many cases exceed one. In the results reported below, I use a smoothing procedure based on equation (5) to generate the cost shares used in constructing the TFP index. For each industry, I estimate the following regression by OLS over all time periods $t$ and countries $\mathrm{c}$ :

$$
\mathrm{s}_{\mathrm{ct}}=\beta_{0 \mathrm{c}}+\beta_{1} \ln \left(\mathrm{k}_{\mathrm{ct}} / 1_{\mathrm{ct}}\right)+\epsilon_{\mathrm{ct}}
$$

I use the fitted values from this regression as the labor cost shares in constructing the reported TFP indexes. In cases where the fitted values exceed one I use the sample mean for the industry. For shipbuilding and repairing, the sample mean for labor's share exceeds one, so I use the sample mean for labor's share in all machinery. Of course, this suggests that the TFP index for shipbuilding should be regarded with great skepticism.

Table 1 reports relative $\mathrm{TFP}^{10}$. For each industry, the country and year of comparison is the US level in 1987; this year was chosen because it is a year with complete US observations across industries, and because it represents a year of approximately full employment in the US. The first observation is that few of the entries are close to 100, meaning that for most countries and years the level of TFP is different from the US level in 1987. This general point accords with previous research, and casts doubt on the notion that technology is the same across the sampled countries. Second, there is a great degree of volatility over time within countries, some of which 
seems to be attributable to business cycle effects; for example, US TFP declines during the 198283 recession, and increases thereafter ${ }^{11}$.

Careful scrutiny of Table 1 induces a deep suspicion about data problems. For example,

1. Australian TFP in each industry plummets between 1982 and 1983, a result due to a big jump in measured employment.

2. Italian TFP in motor vehicles nearly quadruples from 1987 to 1988.

3. US TFP in electrical machinery more than doubles from 1986 to 1987.

To the extent that these data problems come from random mis-measurement of outputs, they will not bias the econometric results reported below. To the extent that there is non-random measurement error (e.g. correlated across observations) or there is measurement error in inputs, the econometric results will be biased.

Table 2 offers a summary of the TFP results reported in Table 1. For each industry, the $\log$ of TFP is regressed on country fixed effects and a time trend. The US is the excluded fixed effect, so the exponential of the country fixed effects are average TFP relative to the US during the sample period, after detrending. The elements of Table 2 are these exponentiated estimated fixed effects. For each industry, proportionate differences outside the approximate interval $(0.95,1.05)$ are statistically significantly different from 1.0 at the $5 \%$ confidence level; the only exception is the "other transport equipment" industry, where because of the small sample size none of the proportions is significantly different from 1.0

Table 2 makes it clear that the US was either the leader or co-leader in TFP during the 1980's in six of the eight industries. The US trailed badly only in electrical machinery, and was tied for second with Japan in shipbuilding. In motor vehicles, the US and Japan had a TFP lead of 
20-25\% over a group of countries including Canada, Germany, and Italy. The US was the clear leader in office and computing equipment and (surprisingly?) in radio, TV, and communications equipment.

Table 3 summarizes cross-industry TFP using a version of the multilateral TFP index of equation (3). The index number formula used in Table 3 weights sectoral outputs relative to the mean using revenue shares, and expresses this quantity relative to an index of total capital and labor used in all sectors, where inputs are weighted using cost shares. The formula for comparing country-year b relative to country-year $\mathrm{c}$ is

$$
T F P_{b c}=\left[\prod_{j=1}^{N}\left(\frac{y_{b j}}{\bar{y}_{j}}\right)^{\rho_{b j}}\left(\frac{\bar{y}_{j}}{y_{c j}}\right)^{\rho_{c j}}\right]\left(\frac{\bar{l}}{l_{b}}\right)^{\sigma_{b}}\left(\frac{\bar{k}}{k_{b}}\right)^{1-\sigma_{b}}\left(\frac{l_{c}}{\bar{l}}\right)^{\sigma_{c}}\left(\frac{k_{c}}{\bar{k}}\right)^{1-\sigma_{c}}
$$

where

$$
\begin{aligned}
& \mathrm{y}_{\mathrm{cj}}=\text { real value added in country c by sector } \mathrm{j} \\
& \rho_{\mathrm{cj}}=\left(\mathrm{r}_{\mathrm{cj}}+\overline{\mathrm{r}}_{\mathrm{j}}\right) / 2 \text {, where } \mathrm{r}_{\mathrm{cj}} \text { is the share of total value added in country c accounted for by } \\
& \quad \text { sector } \mathrm{j} . \\
& \mathrm{l}_{\mathrm{c}}=\text { total labor employed in country c (that is, summed over all } \mathrm{N} \text { sectors) } \\
& \left.\mathrm{k}_{\mathrm{c}}=\text { total capital stock in country c (that is, summed over all } \mathrm{N} \text { sectors }\right) \\
& \sigma_{\mathrm{c}}=\left(\mathrm{s}_{\mathrm{c}}+\overline{\mathrm{s}}\right) / 2, \text { where } \mathrm{s}_{\mathrm{c}} \text { is labor's share in total cost in country c. }
\end{aligned}
$$

Overbars indicate averages over all the observations in the sample. The subscripts $b$ and c can refer to any two distinct observations, such as two different countries during the same year, two different countries in different years, or the same country in different years. As with equation (3), 
equation (6) is easiest to understand in the Cobb-Douglas case, when the revenue and cost shares are the same across observations, in which case (6) reduces to

$$
\operatorname{TFP}_{b c}=\left[\prod_{j=1}^{N}\left(\frac{y_{b j}}{y_{c j}}\right)^{r_{j}}\right]\left(\frac{l_{c}}{l_{b}}\right)^{s}\left(\frac{k_{c}}{k_{b}}\right)^{1-s}
$$

The index (6) used in Table 3 has all the same desirable properties as the industry-byindustry index (3) used in Table 1: it is superlative and transitive.

One practical problem with applying (6) is that it is undefined if there are missing observations for a particular industry. Since there are many holes in the data, this makes it impossible to compare many observations. In constructing Table 3, I apply (6) using data on all industries except Aircraft and Other Transport Equipment. Excluding these two industries allows calculation of cross-industry TFP for eight countries on the remaining six industries. Excluding aircraft will lower US relative TFP in machinery and equipment, since the US has a large aircraft industry which has a substantial TFP advantage over other countries.

The information in Table 3 is presented in two ways. In Panel A, each observation is expressed relative to the US in 1987; Panel B presents year by year comparisons relative to the US. Figures 1 and 3 illustrate the data in Panels A and B respectively. In the late 1980s, the United States and Japan were the co-leaders in TFP among the large countries ${ }^{12}$. A group of four countries (Germany, Italy, Canada and Norway) were 10-20\% points behind the US and Japan. Britain, at $60-70 \%$ of US TFP, is the clear laggard among the eight countries in the table. A surprise is that Finland is roughly equal to the US and Japan in TFP. A clue to this is apparent 
from Table 2: Finland's TFP in electrical machinery is very high, and it happens that Finland has a very high share of value added in this sector so that the sector gets large weight in the overall TFP calculation. Panel A of Table 3 shows that of the seven countries with at least nine years of data, only Canada and Japan did not see substantial TFP growth from the early to the late 1980s; United States TFP grew by over $20 \%$. A comparison of Tables 1, 2, and 3 is instructive: the overall numbers in Table 3 mask considerable sectoral TFP differences in Table 2, while the decade-average TFP differences in Table 2 obscure the substantial year to year variations in TFP that are apparent in Tables 1 and 3.

As noted above, one difficulty in interpreting the TFP numbers is that TFP is procyclical. A simple way to adjust for this is to scale sectoral output by a measure of the GDP gap. Table 4 reports TFP where actual output has been replaced by output multiplied by the ratio of potential to actual GDP; in recession years this amounts to attributing greater potential output to a sector than the amount actually produced. Potential GDP is estimated as the log-linear 20 year trend of actual GDP ${ }^{13}$. Figures 2 and 4 illustrate the two panels of Table 4 . The pattern of relative TFP is not greatly affected by this adjustment, as can be seen most clearly by comparing Figure 1 with Figure 2, or Figure 3 with Figure 4.

All four tables suggest that the three largest economies (US, Japan, and Germany) generally have the best TFP performance. This is consistent with industry-level economies of scale being an important determinant of $\mathrm{TFP}^{14}$. Industry-level scale economies are not the sort of scale economies often considered in recent trade models, such as the monopolistic competition trade model summarized by Helpman and Krugman (1985, Chapter 5-7), where industry production functions have constant returns to scale even though individual firm production functions exhibit 
increasing returns ${ }^{15}$. However, in models such as Ethier (1982) where firms value diversity in intermediate inputs, there will be scale economies at the level of national industries if there are transport costs and other trade barriers which prevent costless trade in intermediate goods ${ }^{16}$. This hypothesis is investigated in the next section.

\section{Econometric Estimation of Technology Differences}

This section describes a methodology for calculating cross-country productivity differences by econometric estimation of industry value added production functions. The purpose of the statistical model is to calculate measures of technological difference which explicitly allow for random variation in output, and to allow exploration of some hypotheses about the technology differences. The regression methodology also relies less heavily on economic theory than do index number comparisons of TFP. This is important since, as documented in Harrigan (1997b), there is reason to believe that some of the assumptions which are necessary to construct TFP index numbers are violated in this data set. The cost of econometric analysis is that parameter estimation requires imposing a statistical model on the data, so the econometric results should be regarded as complements to rather than substitutes for the TFP index number calculations.

For a particular industry in country $\mathrm{c}$ in year $\mathrm{t}$, write real value added $\mathrm{y}_{\mathrm{ct}}$ as a function of the real capital stock $\mathrm{k}_{\mathrm{ct}}$ and the level of employment $\mathrm{l}_{\mathrm{ct}}$ :

$$
\mathrm{y}_{\mathrm{ct}}=\mathrm{f}_{\mathrm{ct}}\left(\mathrm{k}_{\mathrm{ct}}, \mathrm{l}_{\mathrm{ct}}\right)
$$

Hicks-neutral technical differences over time and across countries imply that this function can be written as

$$
\mathrm{f}_{\mathrm{ct}}\left(\mathrm{k}_{\mathrm{ct}} \mathrm{l}_{\mathrm{ct}}\right)=\beta_{\mathrm{ct}} \cdot \mathrm{g}\left(\mathrm{k}_{\mathrm{ct}} \mathrm{l}_{\mathrm{ct}}\right)
$$


Here, the factor of proportionality $\beta_{\mathrm{ct}}$ can be interpreted as an index of TFP. If the function $\mathrm{g}\left(\mathrm{k}_{\mathrm{ct}}, 1_{\mathrm{ct}}\right)$ is Cobb-Douglas, (7) can be written as

$$
\ln \mathrm{y}_{\mathrm{ct}}=\alpha_{0 \mathrm{ct}}+\alpha_{1} \ln \mathrm{k}_{\mathrm{ct}}+\alpha_{2} \ln \mathrm{l}_{\mathrm{ct}}
$$

or, subtracting $\ln 1_{\mathrm{ct}}$ from both sides,

$$
\ln \left(\mathrm{y}_{\mathrm{ct}} / 1_{\mathrm{ct}}\right)=\alpha_{0 \mathrm{ct}}+\alpha_{1} \ln \left(\mathrm{k}_{\mathrm{ct}} / 1_{\mathrm{ct}}\right)+\gamma \ln 1_{\mathrm{ct}}
$$

where $\gamma=\alpha_{1}+\alpha_{2}-1$. Equation (10) states that value added per worker depends on capital per worker and total employment. It is straightforward to show that the elasticity of scale of (10) is equal to $1+\gamma$, so that $\gamma$ is a convenient measure of the extent to which the industry production function differs from constant returns to scale.

The results reported in Table 1 make it clear that TFP varies across countries and over time, so any statistical model of cross-country variation in valued added per worker should allow for country effects and time trends. If there are country specific TFP effects which are common across industries, then pooling observations across industries is an efficient estimator. Using $\mathrm{j}$ to denote industries, a statistical model is

$$
\ln \mathrm{y}_{\mathrm{cjt}} / 1_{\mathrm{cjt}}=\beta_{0 \mathrm{c}}+\beta_{1 \mathrm{c}} \cdot \mathrm{t}+\alpha_{\mathrm{j}}+\alpha_{1 \mathrm{j}} \ln \left(\mathrm{k}_{\mathrm{cjt}} / 1_{\mathrm{cjt}}\right)+\gamma_{\mathrm{j}} \ln 1_{\mathrm{cjt}}+\epsilon_{\mathrm{cjt}}
$$

This model involves estimating industry specific intercept and slope terms (the $\alpha$ 's and $\gamma$ ), and in addition supposing that each country's cross-industry average TFP is given by $\beta_{0 c}+\beta_{1 \mathrm{c}} \cdot \mathrm{t}$. An alternative way of modeling TFP differences is to suppose that there are industry specific time trends which are common across countries and that TFP differences are common for a particular country across industries. In this case, the statistical model is

$$
\ln \mathrm{y}_{\mathrm{cjt}} / l_{\mathrm{cjt}}=\beta_{0 \mathrm{c}}+\beta_{1 \mathrm{j}} \cdot \mathrm{t}+\alpha_{\mathrm{j}}+\alpha_{1 \mathrm{j}} \ln \left(\mathrm{k}_{\mathrm{cjt}} 1_{\mathrm{cjt}}\right)+\gamma_{\mathrm{j}} \ln 1_{\mathrm{cjt}}+\epsilon_{\mathrm{cjt}}
$$


Equation (11) is consistent with models of TFP growth with convergence in cross-industry TFP. TFP convergence (or divergence) is measured by differences in the cross-industry growth rate parameters $\beta_{1 \mathrm{c}}$ across countries. Because of the short length of the panel in this paper and the short-term fluctuations in TFP that are evident in Table 1, it is very difficult to accurately estimate these country growth rate parameters, so I do not address convergence in this paper ${ }^{17}$. Equation (12) treats country TFP differences as constant over time, but allows for differential TFP growth rates across sectors. Equation (12) is consistent with TFP convergence or divergence at the level of total manufacturing to the extent that countries change their relative output mix over time.

Because of the short-run fixity of capital and because of labor hoarding, firms do not vary inputs in the short run proportionately with outputs, leading to strong cyclical movement in capacity utilization and measured TFP. A simple way to model this cyclicality is to suppose that capacity output is given by the production function, while actual output exceeds or falls short of capacity by an amount depending on the GDP gap, $\mu=($ actual GDP)/(potential GDP):

$$
\mathrm{y}_{\mathrm{ct}}=\mathrm{f}_{\mathrm{ct}}\left(\mathrm{k}_{\mathrm{ct}}, \mathrm{l}_{\mathrm{ct}}\right) \cdot \mu_{\mathrm{ct}}{ }^{\delta}
$$

The parameter $\delta$ is the elasticity of capacity utilization with respect to the stage of the business cycle, and the specification has the feature that capacity utilization is $100 \%$ when $\mu=1$. If $\delta>1$, then industry capacity utilization is more cyclical than the economy, while $\delta<1$ is the opposite case. Preliminary data mining in cross-country regressions over time indicates that the null hypothesis of $\delta=1$ can never be rejected at traditional significance levels for any industry, so I impose this simplifying restriction in what follows. This leads to the equation to be estimated:

$$
\ln \left(\mathrm{y}_{\mathrm{cjt}} / l_{\mathrm{cjt}}\right)-\ln \mu_{\mathrm{ct}}=\beta_{0 \mathrm{c}}+\beta_{1 \mathrm{j}} \mathrm{t}+\alpha_{\mathrm{j}}+\alpha_{1 \mathrm{j}} \ln \left(\mathrm{k}_{\mathrm{cjt}} / l_{\mathrm{cjj}}\right)+\gamma_{\mathrm{j}} \ln 1_{\mathrm{cjt}}+\epsilon_{\mathrm{cjt}}
$$


Equation (14) includes time trends, so there is unlikely to be autocorrelation in $\left\{\epsilon_{\mathrm{cjt}}\right\}$. However, the variance of $\epsilon_{\mathrm{cjt}}$ is likely to differ by country and industry, and pre-testing rejects the null of constant variance ${ }^{18}$. Consistent estimates of $\sigma_{\mathrm{cj}}^{2}$ can be obtained as averages of the squared OLS residuals for each industry-country pair, but since there are at most ten observations for each industry-country pair such estimates will have a great deal of noise. Therefore, I model $\sigma_{\mathrm{cj}}^{2}$ as depending in a simple way on the partition into industries and countries:

$$
\sigma_{\mathrm{cj}}^{2}=\phi \sigma_{\mathrm{c}} \sigma_{\mathrm{j}}
$$

Consistent estimates of $\sigma_{\mathrm{c}}$ and $\sigma_{\mathrm{j}}$ are the sample standard deviations of the OLS residuals from (14) for each industry $c$ and country $j ; \phi$ is a constant. Equation (15) along with the assumption of normality implies that $\epsilon_{\mathrm{cjt}} \sim \mathrm{N}\left(0, \phi \sigma_{\mathrm{c}} \sigma_{\mathrm{j}}\right)$. Consequently, the feasible generalized least squares (FGLS) estimator of (14) is weighted regression with weights given by $1 / \hat{\sigma}_{\mathrm{cj}}$.

A potentially very serious econometric problem in estimating (14) is correlation between the right hand side variables and the error term. This could occur for two reasons. The first is measurement error in capital and labor. The second is a simultaneity problem: if industry employment of factors increases due to a productivity shock to the production function, then employment will be positively correlated with the error term. I have attempted to mitigate this simultaneity problem by controlling for the stage of the business cycle which is itself correlated with TFP. The appropriate solution to both the measurement error and simultaneity problems is to use an instrumental variables estimator, but I have not been able to find appropriate instruments. Therefore, the estimated parameters of (14) will not be consistent estimates of the structural parameters, so they should be interpreted with caution. 
The Cobb-Douglas specification for value added is restrictive. In preliminary work, I estimated a translog specification, which differs from the specification in (14) by the inclusion of a quadratic term in the $\log$ of the capital-labor ratio, $\alpha_{3 \mathrm{j}}\left(\ln \mathrm{k}_{\mathrm{cjt}} \mathrm{c}_{\mathrm{cjt}}\right)$. The translog is a flexible functional form, which is also a second order approximation to the constant-elasticity-ofsubstitution (CES) production function (see Kmenta, 1986, pg. 515). In this preliminary work, the correlation between the estimates $\hat{\alpha}_{1 \mathrm{j}}$ and $\hat{\alpha}_{3 \mathrm{j}}$ was virtually -1 for each industry $\mathrm{j}$. A way of expressing this result is that the data can accurately estimate $\alpha_{1 \mathrm{j}}+\alpha_{3 \mathrm{j}}$, but that it is very uninformative about $\alpha_{1 j}-\alpha_{3 j}$. As a consequence of the data's inability to separately identify $\alpha_{3 j}$, all the results which follow set $\alpha_{3 \mathrm{j}} \equiv 0$ and are variants of the Cobb-Douglas specification.

\section{Results}

Table 5 reports estimates of three variants of equation (14) ${ }^{19}$. The estimator in each case is FGLS, as described above. Model 1 is the otherwise unrestricted equation. Model 2 imposes constant returns to scale $\left(\gamma_{\mathrm{j}}=0\right.$, all $\left.\mathrm{j}\right)$, and Model 3 excludes the country fixed effects $\left(\beta_{0 \mathrm{c}}=0\right.$, all i). The unrestricted model allows for two sources of industry productivity differences: differences in the scale of production within an industry and country-specific differences in productivity which are common across industries. The imposition of constant returns to scale in Model 2 means that any cross-country differences in productivity will be attributed to country-specific differences in productivity which are common across industries. Briefly, this is the "constant returns with different technology" hypothesis for explaining cross-country differences in industry productivity. In Model 3, by contrast, the exclusion of country effects means that any cross-country differences in industry productivity will be attributed to non-constant returns to scale, which can be labeled the "non-constant returns with identical technology" hypothesis. To aid interpretation, the 
country fixed effects reported are the exponential of the estimated coefficients; since the US is the excluded category, the exponentiated coefficients measure the proportionate TFP differential in machinery between a country and the US.

In model 1, the estimated coefficients on log capital per worker are reasonable except for an estimate of -0.63 for electrical machinery. A surprise from model 1 is that in no industry is there evidence of increasing returns to scale, and in five of the eight industries there are large and statistically significant estimated decreasing returns. In model 3, which excludes country fixed effects, this result is reversed: there are diseconomies of scale only in the electrical machinery sector, while there are large and statistically significant increasing returns in five of the eight industries.

This pattern of results may be partially explained by the fact that most of the variation in industry size is across countries. This suggests that larger countries may have disproportionately large industries due to moderate economies of scale, but that unrestricted estimation with this small data set can not sharply distinguish between country fixed effects and scale economies. This interpretation is strengthened by noting the change in the pattern of country fixed effects between models 1 and 2: when constant returns are imposed, the country fixed effects increase substantially relative to the US, the largest country in the sample. This negative correlation between estimated country effects and estimated scale economies was also noted by Maskus (1991).

Table 6 reports two types of test statistics which can shed further light on these issues. The first part of the table reports standard F-tests of the linear restrictions embodied in models 2 and 3; these restrictions are rejected at any conventional significance level. The second part of the 
table reports posterior odds ratios of the various combinations of hypotheses ${ }^{20}$. These odds ratios reflect the relative conditional probabilities of the different models, given equal prior probabilities and uninformative prior distributions. If we let $\mathrm{ESS}_{1}$ denote the error sum of squares from the unrestricted Model 1, with $\mathrm{ESS}_{2}$ and $\mathrm{ESS}_{3}$ denoting the error sum of squares from the restricted Model's 2 and 3 respectively, then (for example) the posterior odds in favor of Model 2 over Model 1 is

$$
B_{21}=\left(\frac{E S S_{1}}{E S S_{2}}\right)^{\frac{T}{2}} \cdot T^{\frac{p_{2}}{2}}
$$

where $\mathrm{p}_{2}$ is the number of restrictions embodied in Model 2 and $\mathrm{T}$ is the sample size. For comparison, the relationship between this posterior odds ratio and the usual F-statistic for testing the $\mathrm{p}_{2}$ restrictions is

$$
B_{21}=\left(F \cdot \frac{p_{2}}{T-k}+1\right)^{\frac{T}{2}} \cdot T^{\frac{p_{2}}{2}}
$$

where $\mathrm{F}$ is the F-statistic and $\mathrm{k}$ is the number of parameters in the unrestricted Model 1. The main virtue of the posterior odds approach to hypothesis testing is that it permits the calculation of the relative probability of two hypotheses when both are rejected using classical tests (of course, such sensible comparisons are undefined in the classical framework). The relative likelihood of Model 2 compared to Model $3, \mathrm{~B}_{23}$, is simply the ratio of $\mathrm{B}_{21}$ and $\mathrm{B}_{31}$ :

$$
B_{23}=\left(\frac{E S S_{3}}{E S S_{2}}\right)^{\frac{T}{2}} \cdot T^{\frac{p_{2}-p_{3}}{2}}
$$


where $\mathrm{p}_{3}$ is the number of restrictions embodied in Model 3. The posterior odds ratios indicate that the data support the unrestricted model over either restricted model, but that Model 2 fits the data substantially better than Model 3. Note also that only in Model 2 do all the estimated coefficients on the capital/labor ratio satisfy the theoretical restriction that they lie between zero and one. With a proper prior that embodied this theoretical restriction, the posterior odds ratios would be more favorable to Model 2 than is reported in Table 6.

The country fixed effects estimated in Models 1 and 2, which are estimates of overall TFP in machinery relative to the US level, are mainly reasonable in magnitude and thought-provoking. In Model 1, the US is the statistically significant TFP leader of every country through the 1980's. The laggard is Norway, with TFP of just $34 \%$ of the US level. Japanese TFP ranks second at about $82 \%$ of the US level, while Germany is third at $75 \%$ of the US level. In model 2, which imposes constant returns to scale, Japanese TFP is closer to the US level, at 93\%, which is not statistically significantly different from 100\%. German and Canadian TFP in Model 2 are about $90 \%$ of the US level, which is barely a statistically significant difference. The Australian results are not believable and can probably be attributed to the data anomaly noted above. Among the EC countries in the sample, Italy trails Germany and leads Britain and the Netherlands, each of which substantially trails the US. Finland, Norway and Sweden have TFP comparable to Britain and the Netherlands.

The industry TFP growth rates estimated in Model 1 range from a low of $-1.7 \%$ per year for shipbuilding to a high of $12 \%$ per year for electrical machinery. Given the anomalous estimate for the effect of capital per worker on output in machinery, this large TFP growth rate is 
suspicious and should probably be discounted. Excluding electrical machinery, the fastest growth in TFP occurred in radio, TV, and communications equipment at $7.2 \%$ per year. Office and computing equipment and non-electrical machinery also had rapid TFP growth. This pattern of results does not differ much across the three specifications.

It is instructive to compare the results reported in Table 5 with the TFP index number comparisons reported in Tables 1,2 and 3. Both the index numbers and the regression estimates rank the US as the leading country in TFP, with Japan very close to the US and Germany trailing somewhat. The largest difference is the relative ranking of Finland in Tables 3 and 5: the regression procedure reported in Table 5 does not weigh the good TFP performance of Finland's electrical machinery sector as heavily as the index number procedure of Table 3.

Another way to compare the Table 5 and TFP results is to compare the coefficient on the capital-labor ratio in Model 2 (where constant returns are imposed) with capital's share of total cost. If there is perfect competition in both input and output markets, the two numbers should be approximately the same. As Table 7 shows, the differences are small but statistically significant in most cases ${ }^{21}$. The regression results weight capital more heavily than capital's share in total cost, which is consistent with imperfect competition in input markets which cause the elasticities of outputs to differ from the factor cost shares.

\section{Conclusion}

This paper has constructed and analyzed a data set on real industry inputs and outputs for a group of industrialized countries during the 1980s. The results of the paper confirm the view that there are large and persistent differences in TFP across the industrialized countries. This 
inference was suggested by the TFP comparisons of Table 1, and is supported by the econometric data analysis of the previous section.

The econometric results suggest that industry-level economies of scale are probably not large, and almost certainly can not account for the large size of cross-country TFP differences. This suggests several alternative hypotheses. The first is that there are technological differences across the developed countries, a view which conflicts with the traditional presumption of international trade economists that production sets are the same everywhere. This hypothesis is supported by the data analysis here, in the sense that the hypothesis fits the data better than the increasing returns hypothesis, and also produces the most plausible parameter values of the three statistical models that are estimated. A variant on this hypothesis which does not require supposing differential access to technical knowledge is that there are differences in the legal, social, and political environments across countries which have major effects on TFP. Unfortunately, this is a hard hypothesis to investigate empirically.

A third alternative is that there is systematic measurement error in the components of the TFP index. If this view is correct, better measurement will narrow observed TFP differences. While this can not be ruled out, it should be noted that this paper has used disaggregated price and labor data and the resulting estimated TFP differences, while often somewhat different from previous studies, are not smaller. 


\section{Acknowledgments}

Helpful comments from anonymous referees as well as discussants and seminar participants at the ASSA and Midwest International Economics meetings, the NBER Summer Institute, and Purdue University are gratefully acknowledged. The views expressed in this paper are those of the author and do not necessarily reflect the position of the Federal Reserve Bank of New York or the Federal Reserve System.

\section{References}

Ark, B. van, 1993, Comparative Levels of Manufacturing Productivity in Postwar Europe: Measurement and Comparisons, Oxford Bulletin of Economics and Statistics 52, 343-374.

Ark, B. van, and D. Pilat, 1993, Productivity Levels in Germany, Japan, and the United States:

Differences and Causes, Brookings Papers Microeconomics 2, 1-69.

Bernard, A. B., and C. I. Jones, 1996a, Productivity Across Industries and Countries: Time Series Theory and Evidence, Review of Economics and Statistics 78,135-146.

Bernard, A. B., and C. I. Jones, 1996b, Comparing Apples to Oranges: Productivity Convergence and Measurement Across Industries and Countries, American Economic Review 86, 12161238.

Belsley, D., E. Kuh, and R. Welsch, 1980, Regression Diagnostics: Identifying Influential Data and Sources of Collinearity (John Wiley \& Sons, New York).

Brown, D. K., 1991, Tariffs and Capacity Utilization by Monopolistically Competitive Firms, Journal of International Economics 30, 371-381. 
Caves, D. W., L. R. Christensen, and W. E. Diewert, 1982, Multilateral Comparisons of Output, Input, and Productivity using Superlative Index Numbers, The Economic Journal 92, 73-86.

Chambers, R. G., 1988, Applied Production Analysis, (Cambridge University Press, Cambridge, England).

Costello, D. M., 1993, A Cross-Country, Cross-Industry Comparison of Productivity Growth, Journal of Political Economy 101, 207-222.

Diewert, W. E., 1992, The Measurement of Productivity, Bulletin of Economic Research 44, 163198.

Diewert, W. E., 1976, Exact and Superlative Index Numbers, Journal of Econometrics 4, 115145.

Dollar, D., W. Baumol, and E. N. Wolff, 1988, The Factor Price Equalization Model and Industry Labor Productivity: an Empirical Test Across Countries, in: R. C. Feenstra, ed., Empirical Methods for International Trade (MIT Press, Cambridge, MA).

Dollar, D., and E. N. Wolff, 1993, Competitiveness, Convergence, and International Specialization (MIT Press, Cambridge, MA).

Ethier, W., 1982, National and International Returns to Scale in the Modern Theory of International Trade, American Economic Review 72, 389-405.

Harrigan, J., 1995, Factor Endowments and the International Location of Production: Econometric Evidence for the OECD, 1970-1985, Journal of International Economics 39, $123-141$.

Harrigan, J., 1997a, Technology, Factor Supplies and International Specialization: Estimating the Neoclassical Model, The American Economic Review 87, 475-494. 
Harrigan, J, 1997b, Cross-Country Comparisons of Industry Total Factor Productivity: Theory and Evidence, Federal Reserve Bank of New York Research Paper no. 9734.

Helpman, E., and P. Krugman, 1985, Market Structure and Foreign Trade (MIT Press, Cambridge, MA).

Hooper, P. and K. A. Larin, 1989, International Comparisons of Labor Costs in Manufacturing, Review of Income and Wealth Series 354 (December).

International Labor Organization, various years, Year Book of Labor Statistics (ILO, New York)

Jorgenson, D. W., 1990, Productivity and Economic Growth, in: E. R. Berndt and J. E. Triplett, eds., Fifty Years of Economic Measurement, (University of Chicago Press, Chicago).

Jorgenson, D. W., M. Kuroda, and M. Nishimizu, 1987, Japan-U.S. Industry-Level Productivity Comparisons, 1960-1979, Journal of the Japanese and International Economies 1, 1-30.

Jorgenson, D. W., and M. Kuroda, 1990, Productivity and International Competitiveness in Japan and the United States, 1960-1985, in: C. R. Hulten, ed., Productivity Growth in Japan and the United States (University of Chicago Press, Chicago).

Kmenta, J., 1986, Elements of Econometrics (Macmillan, New York).

Lancaster, K., 1984, Protection and Product Differentiation, in: H. Kierzskowski, ed., Monopolistic Competition and International Trade (Oxford University Press, Oxford).

Leamer, E. E., 1978, Specification Searches (John Wiley and Sons, New York). 
Maskus, K. E., 1991, Comparing International Trade Data and Product and National Characteristics Data for the Analysis of Trade Models, in: P. Hooper and J. D. Richardson, eds., International Economic Transactions: Issues in Measurement and Empirical Research (University of Chicago Press for the NBER, Chicago).

Morrison, C. J., 1993, A Microeconomic Approach to the Measurement of Economic Performance (Springer-Verlag, New York).

OECD Department of Economics and Statistics, 1987, Purchasing Power Parities and Real Expenditures, 1985 (OECD, Paris).

OECD, 1992a, The OECD STAN Database for Structural Analysis (OECD, Paris).

OECD Statistics Directorate, 1992b, Purchasing Power Parities and Real Expenditures, 1990, Volume 1: Results (OECD, Paris).

OECD, 1996, ISDB 96: International Sectoral Database, 1960-1995 (OECD, Paris).

Trefler, D., 1993, International Factor Price Differences: Leontief was Right!, Journal of Political Economy 101, 961-987.

Trefler, D., 1995, The Case of the Missing Trade and Other Mysteries, American Economic Review 85, 1029-1046.

Ward, M., 1985, Purchasing Power Parities and Real Expenditures in the OECD (OECD, Paris). 
Table 1 - Total Factor Productivity, relative to US Level in 1987

\begin{tabular}{|c|c|c|c|c|c|c|c|}
\hline Country & Year & $\begin{array}{l}\text { Non-Elec- } \\
\text { trical } \\
\text { Machinery }\end{array}$ & $\begin{array}{l}\text { Office \& } \\
\text { Computing } \\
\text { Equipment }\end{array}$ & $\begin{array}{l}\text { Electrical } \\
\text { Machinery, } \\
\text { exc. comm. }\end{array}$ & $\begin{array}{l}\text { Radio, TV, } \\
\text { \& Commun- } \\
\text { ications eq. }\end{array}$ & $\begin{array}{l}\text { Motor } \\
\text { Vehicles }\end{array}$ & Aircraft \\
\hline \multirow[t]{6}{*}{ Australia } & 80 & & & 223 & 108 & 88 & \\
\hline & 81 & & & 235 & 118 & 87 & \\
\hline & 82 & & & 245 & 136 & 94 & \\
\hline & 83 & & & 135 & 84 & 52 & \\
\hline & 84 & & & 134 & 97 & 58 & \\
\hline & 85 & & & 134 & 97 & 58 & \\
\hline \multirow[t]{9}{*}{ Britain } & 80 & 40 & 44 & 52 & 33 & 25 & \\
\hline & 81 & 38 & 43 & 56 & 38 & 25 & \\
\hline & 82 & 41 & 49 & 70 & 46 & 28 & \\
\hline & 83 & 43 & 51 & 77 & 52 & 31 & \\
\hline & 84 & 49 & 55 & 95 & 65 & 36 & \\
\hline & 85 & 58 & 62 & 116 & 76 & 43 & 39 \\
\hline & 86 & 61 & 59 & 113 & 72 & 44 & 46 \\
\hline & 87 & 65 & 63 & 108 & 68 & 41 & 42 \\
\hline & 88 & 65 & 69 & 113 & 72 & 44 & 45 \\
\hline \multirow[t]{9}{*}{ Canada } & 80 & 122 & 60 & 117 & 89 & 67 & 87 \\
\hline & 81 & 107 & 54 & 122 & 85 & 61 & 95 \\
\hline & 82 & 84 & 51 & 110 & 82 & 57 & 77 \\
\hline & 83 & 75 & 42 & 105 & 71 & 79 & 41 \\
\hline & 84 & 85 & 45 & 113 & 77 & 88 & 64 \\
\hline & 85 & 89 & 43 & 125 & 74 & 87 & 65 \\
\hline & 86 & 99 & 39 & 130 & 75 & 75 & 56 \\
\hline & 87 & 100 & 43 & 137 & 88 & 64 & 65 \\
\hline & 88 & 108 & 53 & 161 & 94 & 73 & 60 \\
\hline \multirow[t]{10}{*}{ Finland } & 80 & 49 & 90 & 81 & 31 & 32 & \\
\hline & 81 & 53 & 99 & 89 & 38 & 31 & \\
\hline & 82 & 56 & 93 & 99 & 56 & 31 & \\
\hline & 83 & 56 & 79 & 108 & 67 & 34 & \\
\hline & 84 & 67 & 89 & 121 & 69 & 38 & \\
\hline & 85 & 85 & 75 & 152 & 91 & 45 & \\
\hline & 86 & 83 & 84 & 164 & 96 & 47 & \\
\hline & 87 & 109 & 109 & 178 & 121 & 50 & \\
\hline & 88 & 114 & 104 & 218 & 105 & 54 & \\
\hline & 89 & 119 & 57 & 254 & 132 & 58 & 46 \\
\hline
\end{tabular}


Table 1, continued

\begin{tabular}{|c|c|c|c|c|c|c|c|}
\hline Country & Year & $\begin{array}{l}\text { Non-Elec- } \\
\text { trical } \\
\text { Machinery }\end{array}$ & $\begin{array}{l}\text { Office \& } \\
\text { Computing } \\
\text { Equipment }\end{array}$ & $\begin{array}{l}\text { Electrical } \\
\text { Machinery, } \\
\text { exc. comm. }\end{array}$ & $\begin{array}{l}\text { Radio, TV, } \\
\text { \& Commun- } \\
\text { ications eq. }\end{array}$ & $\begin{array}{l}\text { Motor } \\
\text { Vehicles }\end{array}$ & Aircraft \\
\hline \multirow[t]{10}{*}{ Germany } & 80 & 62 & 51 & 63 & 61 & 63 & 62 \\
\hline & 81 & 60 & 51 & 62 & 69 & 66 & 68 \\
\hline & 82 & 57 & 56 & 67 & 79 & 71 & 67 \\
\hline & 83 & 58 & 59 & 75 & 88 & 75 & 64 \\
\hline & 84 & 64 & 62 & 89 & 97 & 78 & 70 \\
\hline & 85 & 78 & 67 & 105 & 112 & 91 & 74 \\
\hline & 86 & 74 & 64 & 103 & 102 & 78 & 69 \\
\hline & 87 & 78 & 61 & 101 & 102 & 75 & 70 \\
\hline & 88 & 78 & 66 & 104 & 110 & 73 & 72 \\
\hline & 89 & 80 & 60 & 95 & 110 & 72 & 84 \\
\hline \multirow[t]{4}{*}{ Italy } & 85 & 76 & 48 & 152 & 77 & 53 & 72 \\
\hline & 86 & 76 & 44 & 148 & 71 & 49 & 63 \\
\hline & 87 & 84 & 43 & 149 & 73 & 54 & \\
\hline & 88 & & & & & 199 & \\
\hline \multirow[t]{10}{*}{ Japan } & 80 & 77 & 61 & 103 & 63 & 105 & \\
\hline & 81 & 77 & 56 & 103 & 67 & 94 & \\
\hline & 82 & 73 & 57 & 109 & 65 & 83 & \\
\hline & 83 & 67 & 58 & 107 & 64 & 79 & \\
\hline & 84 & 64 & 78 & 112 & 70 & 76 & \\
\hline & 85 & 80 & 57 & 118 & 66 & 80 & \\
\hline & 86 & 79 & 54 & 120 & 63 & 74 & \\
\hline & 87 & 84 & 53 & 131 & 69 & 83 & \\
\hline & 88 & 94 & 59 & 159 & 86 & 101 & \\
\hline & 89 & 98 & 62 & 180 & 96 & 115 & \\
\hline \multirow[t]{9}{*}{ Netherlands } & 80 & 51 & 50 & & & 138 & \\
\hline & 81 & 53 & 42 & & & 92 & \\
\hline & 82 & 55 & 44 & & & 51 & \\
\hline & 83 & 53 & 54 & & & 53 & \\
\hline & 84 & 59 & 72 & & & 58 & \\
\hline & 85 & 76 & 44 & & & 59 & \\
\hline & 86 & 78 & 59 & & & 61 & \\
\hline & 87 & 89 & 45 & & & 56 & \\
\hline & 88 & 84 & 49 & & & 82 & \\
\hline
\end{tabular}


Table 1, continued

\begin{tabular}{|c|c|c|c|c|c|c|c|}
\hline Country & Year & $\begin{array}{l}\text { Non-Elec- } \\
\text { trical } \\
\text { Machinery }\end{array}$ & $\begin{array}{l}\text { Office \& } \\
\text { Computing } \\
\text { Equipment }\end{array}$ & $\begin{array}{l}\text { Electrical } \\
\text { Machinery, } \\
\text { exc. comm. }\end{array}$ & $\begin{array}{l}\text { Radio, TV, } \\
\text { \& Commun- } \\
\text { ications eq. }\end{array}$ & $\begin{array}{l}\text { Motor } \\
\text { Vehicles }\end{array}$ & Aircraft \\
\hline \multirow[t]{10}{*}{ Norway } & 80 & 50 & 27 & 69 & 33 & 32 & 38 \\
\hline & 81 & 51 & 32 & 86 & 37 & 31 & 41 \\
\hline & 82 & 51 & 37 & 85 & 41 & 31 & 36 \\
\hline & 83 & 51 & 37 & 92 & 49 & 31 & 32 \\
\hline & 84 & 56 & 40 & 98 & 56 & 33 & 32 \\
\hline & 85 & 70 & 40 & 117 & 61 & 36 & 36 \\
\hline & 86 & 77 & 44 & 140 & 69 & 36 & 24 \\
\hline & 87 & 87 & 32 & 155 & 78 & 36 & 41 \\
\hline & 88 & 85 & 30 & 159 & 81 & 37 & 39 \\
\hline & 89 & 89 & 26 & 165 & 77 & 38 & 39 \\
\hline \multirow[t]{10}{*}{ USA } & 80 & 103 & 99 & 54 & 119 & 73 & \\
\hline & 81 & 101 & 97 & 59 & 111 & 71 & \\
\hline & 82 & 91 & 91 & 32 & 111 & 68 & 92 \\
\hline & 83 & 88 & 81 & 29 & 108 & 91 & 95 \\
\hline & 84 & 91 & 88 & 26 & 115 & 102 & 104 \\
\hline & 85 & 97 & 79 & 43 & 108 & 105 & 105 \\
\hline & 86 & 102 & 81 & 43 & 106 & 100 & 99 \\
\hline & 87 & 100 & 100 & 100 & 100 & 100 & 100 \\
\hline & 88 & 108 & 110 & 114 & 116 & 117 & 103 \\
\hline & 89 & 112 & 114 & 115 & 122 & 125 & 107 \\
\hline
\end{tabular}


Table 2 - Summary of Table 1, Average TFP relative to US Average TFP, detrended

\begin{tabular}{||l|l|l|l|l|l|l|r|l||}
\hline & $\begin{array}{l}\text { Non- } \\
\text { Electrical } \\
\text { Machinery }\end{array}$ & $\begin{array}{l}\text { Office \& } \\
\text { Computer } \\
\text { Equipmnt }\end{array}$ & $\begin{array}{l}\text { Electrical } \\
\text { Machine- } \\
\text { ry }\end{array}$ & $\begin{array}{l}\text { Radio, } \\
\text { TV, } \\
\text { Comm. }\end{array}$ & $\begin{array}{l}\text { Motor } \\
\text { Vehicles }\end{array}$ & $\begin{array}{l}\text { Ship- } \\
\text { building }\end{array}$ & Aircraft & $\begin{array}{l}\text { Other } \\
\text { Trans. } \\
\text { Equip. }\end{array}$ \\
\hline Australia & & & 262 & 86 & 61 & 67 & & \\
\hline Britain & 52 & 58 & 166 & 52 & 37 & 38 & 42 & \\
\hline Canada & 99 & 51 & 241 & 76 & 78 & 81 & 66 & 96 \\
\hline Finland & 76 & 93 & 256 & 66 & 44 & 51 & 46 & \\
\hline Germany & 69 & 64 & 158 & 82 & 79 & 78 & 69 & \\
\hline Italy & 73 & 48 & 245 & 60 & 73 & 52 & 67 & 83 \\
\hline Japan & 79 & 63 & 229 & 63 & 94 & 100 & & \\
\hline Netherlnd & 67 & 54 & & & 75 & 119 & & 84 \\
\hline Norway & 65 & 36 & 209 & 50 & 36 & 45 & 35 & \\
\hline Sweden & & & & & & 50 & & \\
\hline
\end{tabular}

Notes to Table 2: The numbers in this table are regression-based summaries of the TFP data in

Table 1. Each entry is 100 times the exponential of the country fixed effect $D_{c}$ in the following regression for sector $\mathrm{j}$ :

$$
\ln \mathrm{TFP}_{\mathrm{cjt}}=\mathrm{D}_{\mathrm{cj}}+\delta_{\mathrm{j}} \cdot \mathrm{t}+\epsilon_{\mathrm{cjt}}
$$

where $\ln \mathrm{TFP}_{\mathrm{cjt}}$ is the $\log$ of industry $\mathrm{j}$ TFP in country $\mathrm{c}$ in year $\mathrm{t}$ relative to the sample mean TFP of industry j. The United States is the excluded fixed effect, so the entries in the table are percentage differences from the United States. 
Table 3 - Overall TFP in Machinery \& Equipment

\begin{tabular}{|c|c|c|c|c|c|c|c|c|c|c|}
\hline \multicolumn{11}{|c|}{ Panel A: TFP is expressed relative to a base of United States in 1987 $=100$} \\
\hline & 1980 & 1981 & 1982 & 1983 & 1984 & 1985 & 1986 & 1987 & 1988 & 1989 \\
\hline Britain & 35 & 36 & 41 & 44 & 53 & 64 & 63 & 64 & 68 & \\
\hline Canada & 94 & 86 & 76 & 79 & 86 & 88 & 86 & 83 & 93 & \\
\hline Finland & 48 & 52 & 60 & 61 & 69 & 89 & 82 & 105 & 110 & 117 \\
\hline Germany & 63 & 65 & 69 & 73 & 80 & 94 & 89 & 90 & 90 & 86 \\
\hline Italy & & & & & & 79 & 76 & 82 & & \\
\hline Japan & 91 & 92 & 90 & 84 & 87 & 91 & 87 & 95 & 112 & 121 \\
\hline Norway & 51 & 52 & 52 & 53 & 56 & 66 & 73 & 79 & 81 & 83 \\
\hline United States & 89 & 88 & 81 & 82 & 87 & 91 & 93 & 100 & 111 & 114 \\
\hline \multicolumn{11}{|c|}{ Panel B: TFP is expressed relative to a base of United States in each year $=100$} \\
\hline Britain & 39 & 41 & 51 & 54 & 61 & 70 & 68 & 64 & 61 & \\
\hline Canada & 106 & 98 & 93 & 96 & 99 & 97 & 93 & 83 & 84 & \\
\hline Finland & 54 & 59 & 74 & 75 & 80 & 97 & 88 & 105 & 99 & 103 \\
\hline Germany & 71 & 74 & 85 & 89 & 92 & 104 & 95 & 90 & 81 & 76 \\
\hline Italy & & & & & & 86 & 82 & 82 & & \\
\hline Japan & 102 & 105 & 111 & 103 & 100 & 100 & 94 & 95 & 100 & 106 \\
\hline Norway & 58 & 59 & 64 & 64 & 64 & 73 & 78 & 79 & 72 & 72 \\
\hline United States & 100 & 100 & 100 & 100 & 100 & 100 & 100 & 100 & 100 & 100 \\
\hline
\end{tabular}

Notes to Table 3: The TFP comparisons in this table are index numbers using the industry level data presented in Table 1. Data for two of the eight industries, Aircraft and Other Transport Equipment, are excluded. For the index number formula used in this table, see equation (6) in the text. Panel A of this table is graphed in Figure 1, and Panel B is graphed in Figure 3. 
Table 4 - Overall TFP in Machinery \& Equipment, adjusted for Business Cycle

\begin{tabular}{|c|c|c|c|c|c|c|c|c|c|c|}
\hline \multicolumn{11}{|c|}{ Panel A: TFP is expressed relative to a base of United States in $1987=100$} \\
\hline & 1980 & 1981 & 1982 & 1983 & 1984 & 1985 & 1986 & 1987 & 1988 & 1989 \\
\hline Britain & 36 & 38 & 44 & 46 & 55 & 67 & 64 & 64 & 66 & \\
\hline Canada & 93 & 85 & 80 & 83 & 88 & 89 & 87 & 84 & 93 & \\
\hline Finland & 48 & 52 & 61 & 62 & 70 & 90 & 84 & 107 & 110 & 115 \\
\hline Germany & 61 & 65 & 71 & 75 & 82 & 97 & 91 & 93 & 92 & 87 \\
\hline Italy & & & & & & 81 & 79 & 84 & & \\
\hline Japan & 91 & 92 & 91 & 86 & 89 & 93 & 90 & 97 & 113 & 122 \\
\hline Norway & 49 & 51 & 53 & 53 & 55 & 64 & 70 & 78 & 83 & 90 \\
\hline United States & 90 & 90 & 87 & 87 & 89 & 92 & 94 & 100 & 109 & 112 \\
\hline \multicolumn{11}{|c|}{ Panel B: TFP is expressed relative to a base of United States in each year $=100$} \\
\hline Britain & 40 & 42 & 50 & 53 & 62 & 72 & 68 & 64 & 60 & \\
\hline Canada & 103 & 94 & 91 & 96 & 100 & 97 & 93 & 84 & 85 & \\
\hline Finland & 53 & 59 & 70 & 71 & 79 & 97 & 90 & 107 & 100 & 102 \\
\hline Germany & 68 & 72 & 81 & 86 & 93 & 105 & 97 & 93 & 84 & 77 \\
\hline Italy & & & & & & 87 & 84 & 84 & & \\
\hline Japan & 100 & 103 & 105 & 99 & 100 & 100 & 96 & 97 & 103 & 108 \\
\hline Norway & 54 & 57 & 60 & 61 & 62 & 70 & 75 & 78 & 76 & 80 \\
\hline United States & 100 & 100 & 100 & 100 & 100 & 100 & 100 & 100 & 100 & 100 \\
\hline
\end{tabular}

Notes to Table 4: This table differs from Table 3 by multiplying each country's output by the ratio of trend to actual GDP. This is a way of smoothing out TFP variability which is caused by business cycle variation in capacity utilization. See also the notes to Table 3. Panel A of this table is graphed in Figure 2, and Panel B is graphed in Figure 4. 


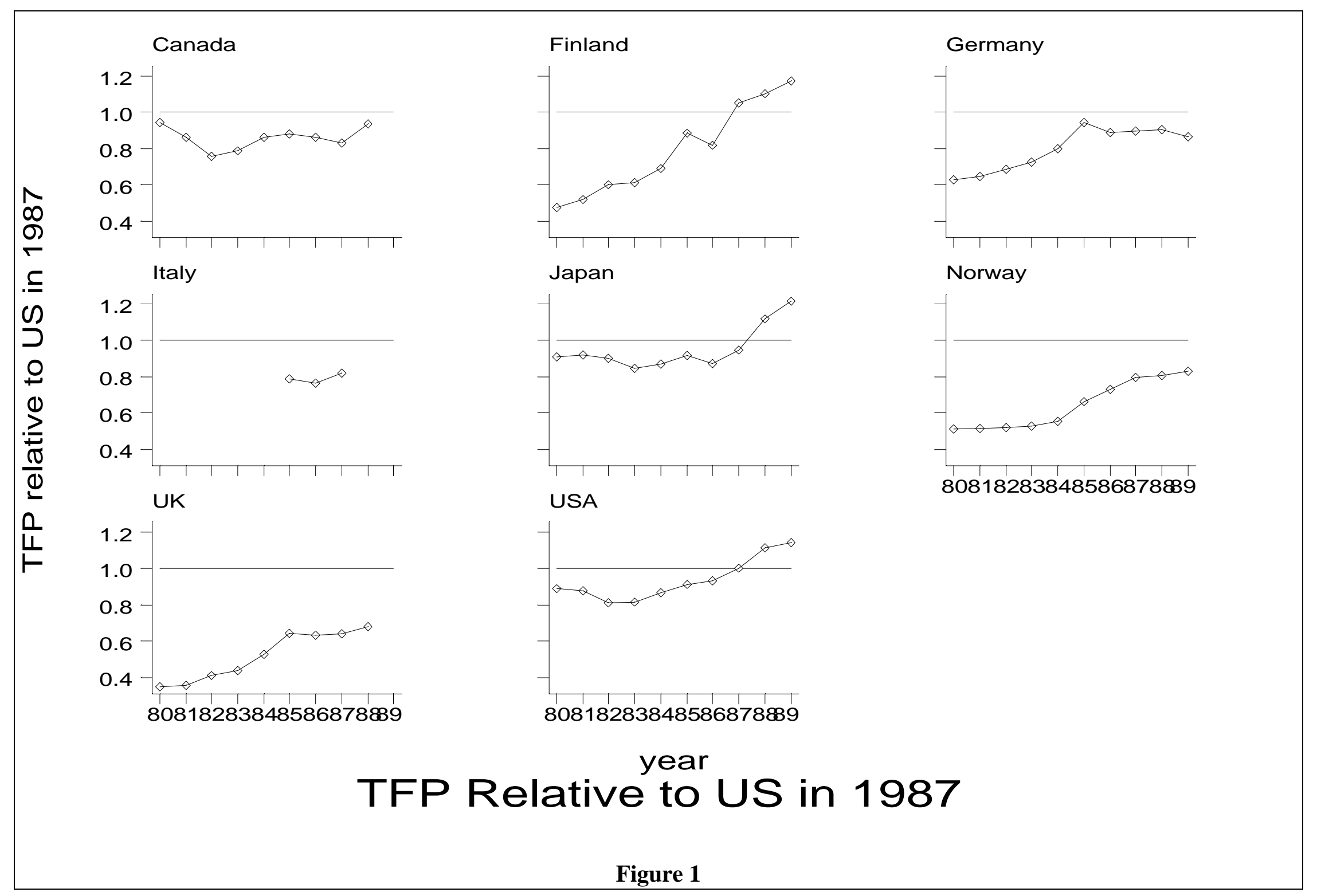




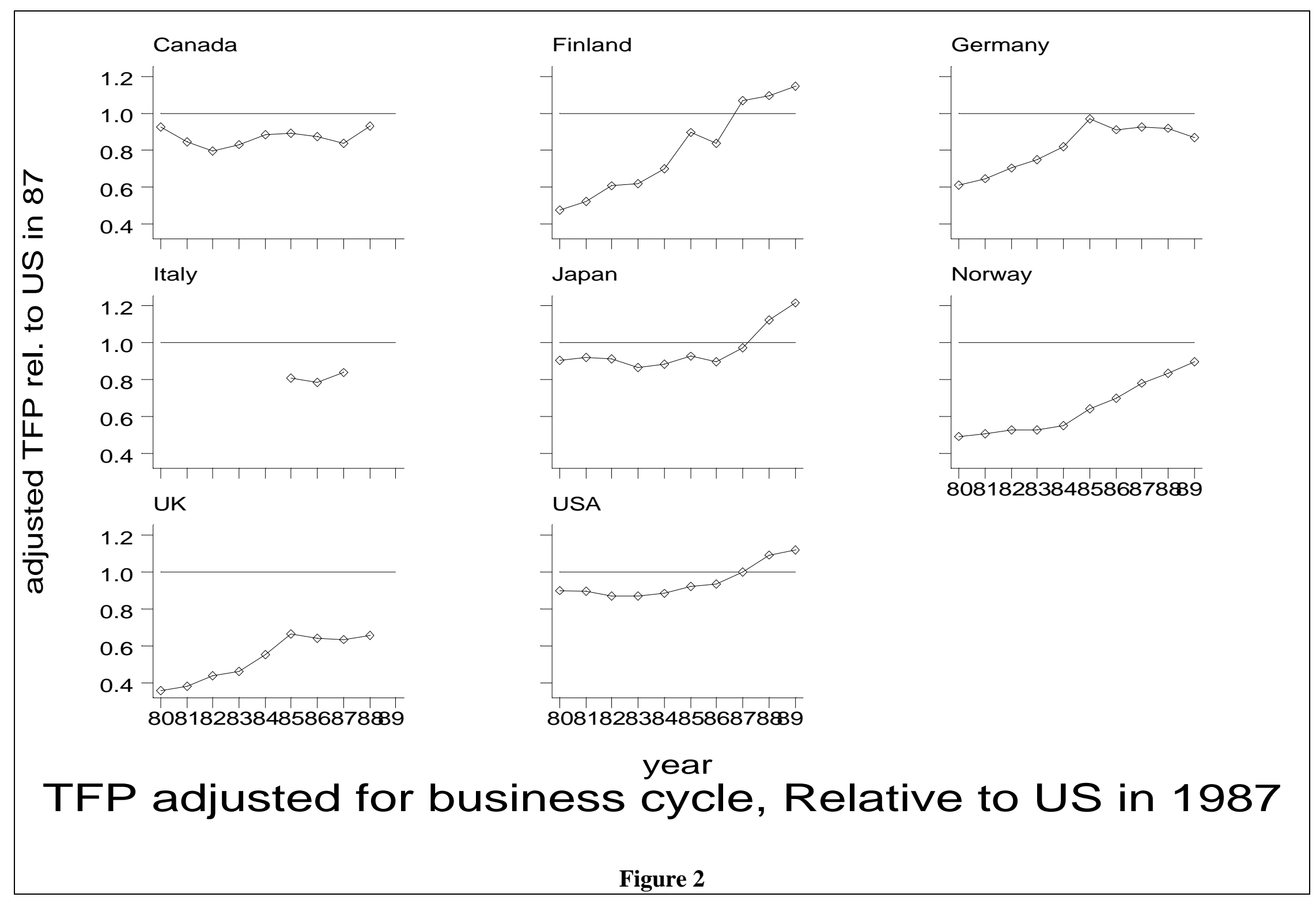




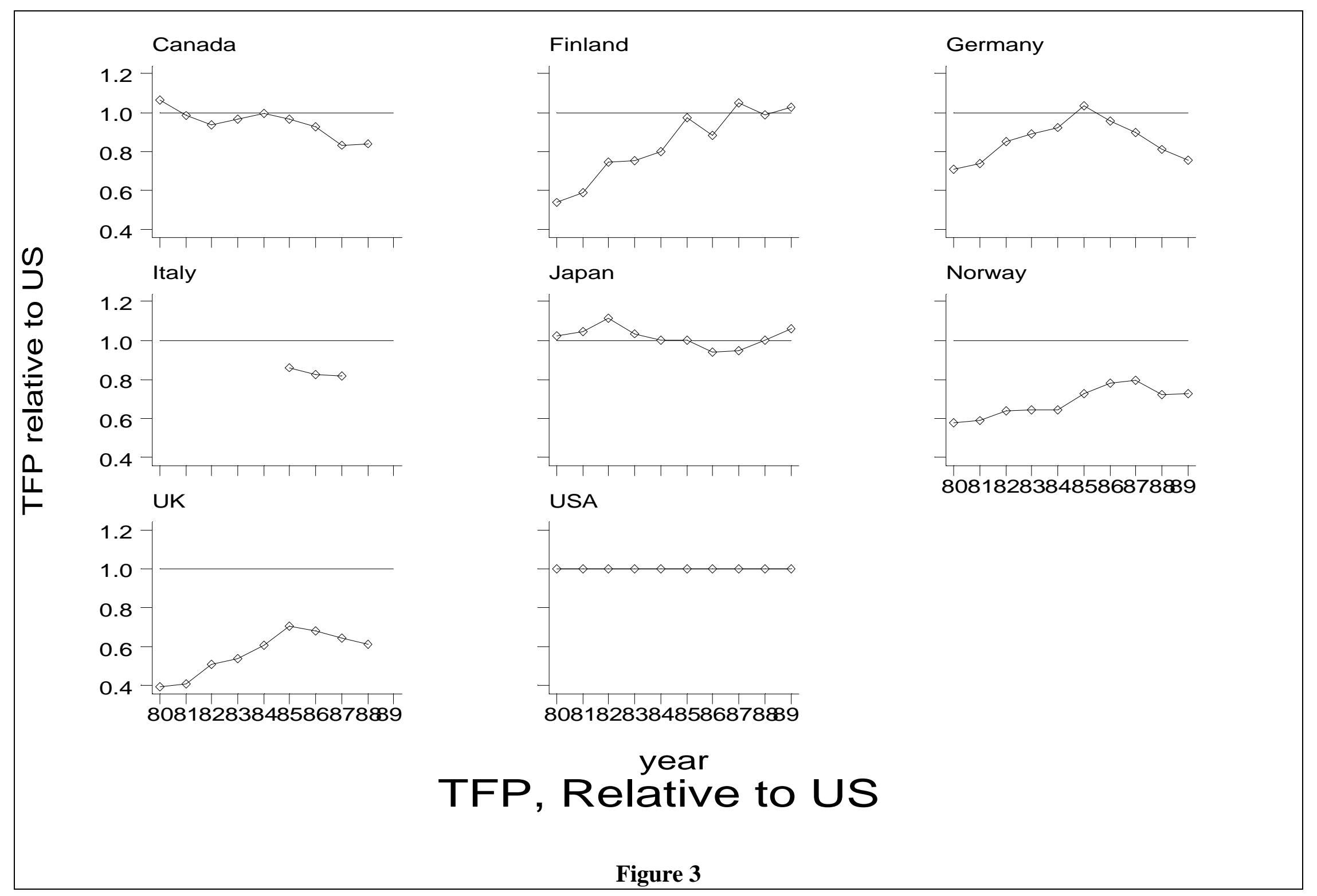




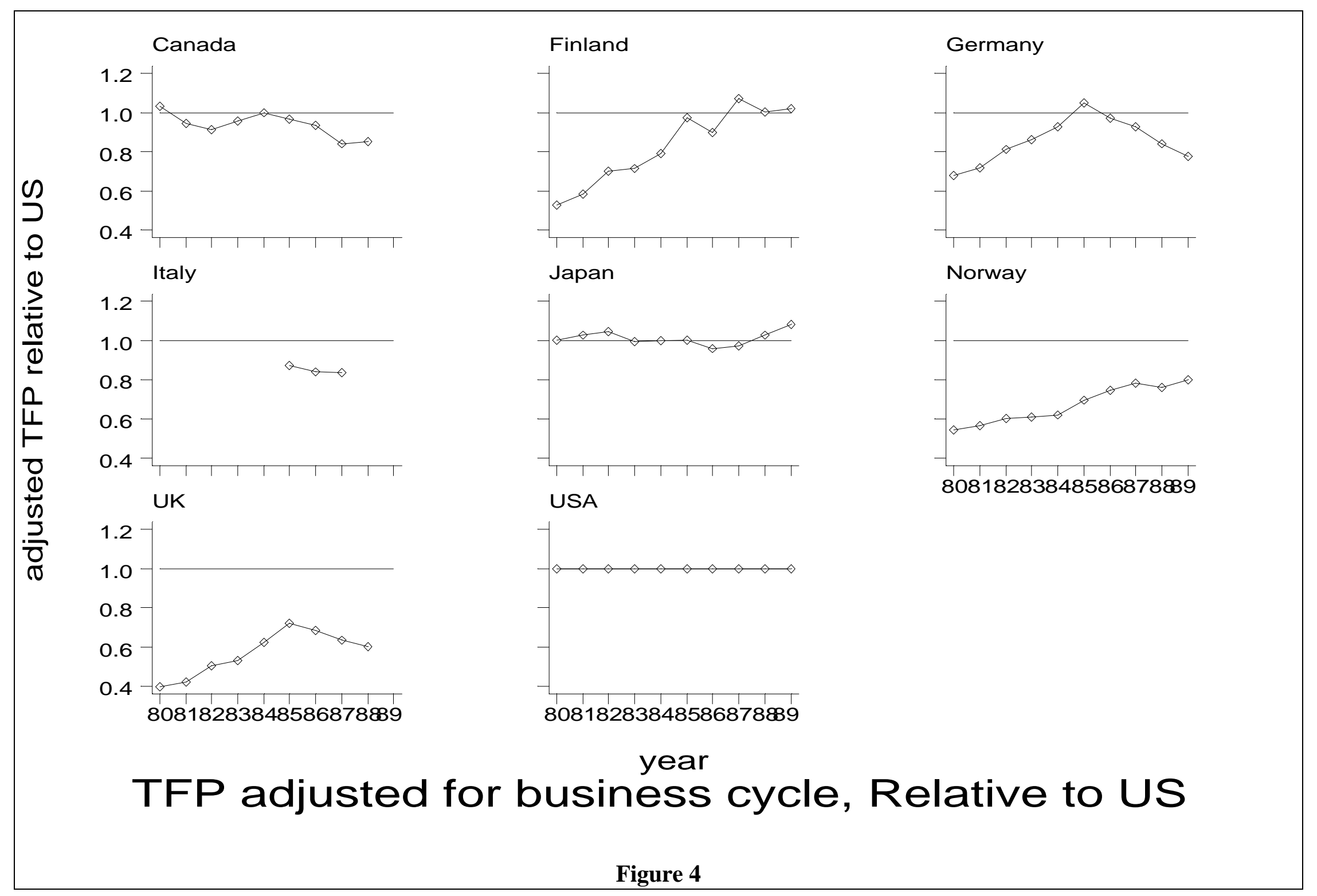




\section{Notes to Figures:}

Figure 1 presents the data in Panel A of Table 3.

Figure 2 presents the data in Panel A of Table 4.

Figure 3 presents the data in Panel B of Table 3.

Figure 4 presents the data in Panel B of Table 4. 


\begin{tabular}{|c|c|c|c|c|c|c|}
\hline \multicolumn{7}{|c|}{ Table 5 - Estimates of Equation (14) } \\
\hline \multicolumn{7}{|c|}{$\begin{array}{l}\text { dependent variable: Log Value Added per Worker, adjusted for capacity utilization } \\
\text { number of observations }=566\end{array}$} \\
\hline & \multicolumn{2}{|c|}{$\begin{array}{l}\text { Model } 1 \\
\mathrm{R}^{2}=0.80\end{array}$} & \multicolumn{2}{|c|}{$\begin{array}{l}\text { Model } 2 \\
\mathrm{R}^{2}=0.71\end{array}$} & \multicolumn{2}{|c|}{$\begin{array}{l}\text { Model } 3 \\
\mathrm{R}^{2}=0.64 \\
\end{array}$} \\
\hline & coef. & $\mathrm{t}$ & coef. & $\mathrm{t}$ & coef. & $\mathrm{t}$ \\
\hline \multicolumn{7}{|l|}{ Log Capital per Worker } \\
\hline Non-electrical Machinery & 0.232 & 2.84 & 0.441 & 5.04 & 0.390 & 4.09 \\
\hline Office \& Computing Equipment & 0.209 & 4.23 & 0.256 & 4.62 & 0.289 & 4.88 \\
\hline Electrical machinery, except comm. & -0.631 & -6.23 & 0.336 & 3.48 & -0.216 & -1.89 \\
\hline Radio, TV, \& comm. equipment & 0.222 & 2.80 & 0.388 & 4.78 & 0.580 & 6.12 \\
\hline Shipbuilding \& Repairing & 0.422 & 4.15 & 0.288 & 3.05 & 0.522 & 4.26 \\
\hline Motor Vehicles & 0.548 & 6.58 & 0.714 & 7.59 & 0.938 & 9.67 \\
\hline Aircraft & 0.189 & 1.97 & 0.363 & 3.20 & 0.567 & 4.72 \\
\hline Other transport equipment & 0.342 & 3.07 & 0.291 & 2.85 & 0.320 & 2.51 \\
\hline \multicolumn{7}{|l|}{ Log Industry Employment } \\
\hline Non-electrical Machinery & -0.157 & -5.37 & & & 0.031 & 1.45 \\
\hline Office \& Computing Equipment & -0.066 & -2.66 & & & 0.087 & 4.60 \\
\hline Electrical machinery, except comm. & -0.373 & -12.3 & & & -0.168 & -6.58 \\
\hline Radio, TV, \& comm. equipment & -0.100 & -4.14 & & & 0.058 & 3.06 \\
\hline Shipbuilding \& Repairing & -0.051 & -1.21 & & & 0.133 & 3.54 \\
\hline Motor Vehicles & -0.018 & -0.87 & & & 0.096 & 6.35 \\
\hline Aircraft & -0.008 & -0.34 & & & 0.160 & 7.53 \\
\hline Other transport equipment & -0.276 & -2.59 & & & 0.055 & 0.51 \\
\hline
\end{tabular}




\begin{tabular}{|c|c|c|c|c|c|c|}
\hline \multicolumn{7}{|c|}{ Table 5 - Estimates of Equation (14) } \\
\hline \multicolumn{7}{|c|}{$\begin{array}{l}\text { dependent variable: } \log \text { Value Added per Worker, adjusted for capacity utilization } \\
\text { number of observations }=566\end{array}$} \\
\hline & \multicolumn{2}{|c|}{$\begin{array}{l}\text { Model } 1 \\
\mathrm{R}^{2}=0.80\end{array}$} & \multicolumn{2}{|c|}{$\begin{array}{l}\text { Model } 2 \\
\mathrm{R}^{2}=0.71 \\
\end{array}$} & \multicolumn{2}{|c|}{$\begin{array}{l}\text { Model } 3 \\
\mathrm{R}^{2}=0.64 \\
\end{array}$} \\
\hline & coef. & $\mathrm{t}$ & coef. & $\mathrm{t}$ & coef. & $\mathrm{t}$ \\
\hline \multicolumn{7}{|l|}{ Industry Trends } \\
\hline Non-electrical Machinery & 0.051 & 5.70 & 0.045 & 4.35 & 0.047 & 4.00 \\
\hline Office \& Computing Equipment & 0.030 & 2.76 & 0.025 & 1.95 & 0.019 & 1.40 \\
\hline Electrical machinery, except comm. & 0.121 & 10.88 & 0.067 & 5.01 & 0.094 & 6.75 \\
\hline Radio, TV, \& comm. equipment & 0.072 & 6.42 & 0.058 & 4.68 & 0.034 & 2.31 \\
\hline Shipbuilding \& Repairing & -0.017 & -1.82 & -0.008 & -0.80 & -0.011 & -0.92 \\
\hline Motor Vehicles & 0.018 & 1.95 & 0.015 & 1.41 & -0.002 & -0.17 \\
\hline Aircraft & 0.000 & -0.01 & -0.010 & -0.60 & -0.041 & -2.39 \\
\hline Other transport equipment & 0.001 & 0.04 & 0.005 & 0.22 & 0.005 & 0.18 \\
\hline \multicolumn{7}{|c|}{ Country Fixed Effects (exponentiated to give proportion of US=1) } \\
\hline Australia & 0.754 & -2.75 & 1.147 & 1.91 & & \\
\hline Britain & 0.470 & -13.35 & 0.618 & -8.74 & & \\
\hline Canada & 0.639 & -5.91 & 0.907 & -2.06 & & \\
\hline Finland & 0.463 & -7.61 & 0.749 & -5.40 & & \\
\hline Germany & 0.748 & -5.97 & 0.896 & -2.24 & & \\
\hline Italy & 0.680 & -5.47 & 0.741 & -4.70 & & \\
\hline Japan & 0.816 & -3.97 & 0.932 & -1.23 & & \\
\hline Netherlands & 0.562 & -6.07 & 0.822 & -3.33 & & \\
\hline Norway & 0.343 & -10.30 & 0.548 & -12.50 & & \\
\hline Sweden & 0.415 & -7.49 & 0.578 & -5.97 & & \\
\hline
\end{tabular}




\section{Table 6 - Test Statistics}

Note: All test statistics are calculated using the FGLS estimates of equation (14).

The different hypotheses are

Model 1: Unrestricted; Variable Returns to Scale/Different Technology

Model 2: $\gamma_{\mathrm{j}}=0$, all $\mathrm{j}$; Constant Returns to Scale/Different Technology

Model 3: $\beta_{0 \mathrm{i}}=0$, all i; Variable Returns to Scale/Identical Technology

\section{F-tests}

Null: $\quad$ Model 2

$\mathrm{F}(8,524)=31.50 \quad 1 \%$ Critical Value $=2.545$

Null: Model 3

$\mathrm{F}(10,524)=41.33 \quad 1 \%$ Critical Value $=2.355$

\section{Posterior Odds Ratios}

$\operatorname{Pr}($ Model $2 \mid$ data $) / \operatorname{Pr}($ Model $1 \mid$ data $)=5.29 \times 10^{-60}$

$\operatorname{Pr}($ Model $3 \mid$ data $) / \operatorname{Pr}($ Model $1 \mid$ data $)=5.77 \times 10^{-86}$

$\operatorname{Pr}($ Model $2 \mid$ data $) / \operatorname{Pr}($ Model $3 \mid$ data $)=9.16 \times 10^{25}$ 


\section{Table 7 - Comparison of Regression \& TFP Weights on Capital}

\begin{tabular}{||l|r|r|r||}
\hline & $(1)$ & $(2)$ & $(3)$ \\
\hline Non-electrical Machinery & 0.441 & 0.201 & 0.006 \\
\hline Office \& Computing Equipment & 0.256 & 0.426 & 0.002 \\
\hline Electrical machinery, except comm. & 0.336 & 0.154 & 0.060 \\
\hline Radio, TV, \& comm. equipment & 0.388 & 0.327 & 0.448 \\
\hline Shipbuilding \& Repairing & 0.288 & 0.055 & 0.014 \\
\hline Motor Vehicles & 0.714 & 0.254 & 0.000 \\
\hline Aircraft & 0.363 & 0.170 & 0.089 \\
\hline Other transport equipment & 0.291 & 0.237 & 0.595 \\
\hline Unweighted average & 0.385 & 0.228 & \\
\hline
\end{tabular}

Notes to Table 7: Column (1) is the coefficient on the capital-labor ratio in Model 2, reproduced from Table 5. Column (2) is the average of capital's weight in the TFP calculations of Table 1. Column (3) is the marginal significance level of the difference between columns (1) and (2). 


\section{Footnotes}

1. Studies of sectoral TFP growth include Costello (1993) and Bernard and Jones (1996a, 1996b).

2. See Harrigan (1997b) for a more detailed summary and critique of previous research on international sectoral TFP comparisons.

3. The data set is called STAN (STructural ANalysis); see OECD 1992a.

4. This approach is also used by Hooper and Larin (1989).

5. Hours worked and occupational data are both from the Year Book of Labour Statistics, various years.

6. I use the 1983 differentials for $1980-82$ and the 1988 differentials for 1989-90. This is a small distortion since these differentials change slowly over time.

7. It is possible to enter the three labor occupational categories separately in a version of (3) rather than first aggregating them using equation (2). The difference in the implicit weights given to the labor categories is second order, and the difference in the calculated levels of TFP appear only in the fourth digit or later.

8. An index number formula is said to be "exact" for a particular functional form if it equals the Fisher "ideal" index for that functional form, where the "ideal" index is the geometric mean of a Paasche and a Laspeyres index. An index is said to be "superlative" if it is exact for a flexible functional form such as the translog. See Diewert (1976).

9. Diewert (1992) is a good survey of different TFP indices and the often subtle issues involved in choosing among them. In a recent paper, Bernard and Jones (1996b) note that the index used by Dollar and Wolff (1993) is unit dependent, and they propose a new "TTP" index as a replacement for the Caves-Christensen-Diewert (CCD) index used in the current paper. Their criticism of the CCD index (pg. 1232) is very confused. They claim that the CCD index "ignores differences in 
factor exponents", which is simply false, and they claim that in, for example, US-Japan comparisons "the rank comparison may depend on whether one uses the Japanese or the U.S. factor share", which is unintelligible since the CCD index uses an average of the country's factor shares rather than one or the other. This criticism does apply to their own TTP index, which they acknowledge. In addition, the TTP index is based on a restricted form of the translog with second order terms set identically equal to zero, so their rejection of the translog's implications for timeseries variation in factor shares applies a fortiori to their own index.

10. Harrigan (1997b) reports a more complete version of Table 1; some results are omitted here in the interests of brevity.

11. These cyclical effects are why the numbers are presented relative to the US level in 1987; year by year comparisons to the US are uninformative because they are dominated by differences across countries in the stage of the business cycle.

12. In Jorgenson, Kuroda and Nishimizu (1987), the authors do not report the levels of relative TFP, but they do report that Japan trailed the US in machinery and equipment in 1979, although they expected Japan to close the gap with the US in the near future (pg. 26). Jorgenson and Kuroda (1990) updates the earlier study, and reports that by the mid-1980's Japan had industry TFP that was equal to or greater than US TFP in many machinery sectors. Their results are quite consistent with the results reported here, which provides some grounds for hoping that the results of value added and gross output TFP comparisons might generally be comparable.

13. The capacity utilization measure $\mu$ has a mean of one by construction, and a sample standard deviation of $2.5 \%$. The standard deviation by country varies from a low of $1.3 \%$ (Japan) to a high of $4.6 \%$ (Norway). A more sophisticated treatment of capacity utilization would define capacity 
as the minimum of the short run average cost curve, but the data required for such an adjustment is not available. See Morrison (1993), Chapter 3.

14. Note that the calculation of the TFP index (3) requires either an assumption of constant returns to scale or a priori knowledge of the degree of scale economies (see Caves, Christensen, and Diewert (1982), pg. 1394).

15. In the Helpman-Krugman model, the scale of production of an individual firm depends on the elasticity of demand. In the tractable case of CES preferences and large numbers of firms, this elasticity is a constant, and changes in industry output are accommodated by changes in the number of firms rather than changes in the scale of existing firms. With more complex preferences which allow for changes in the elasticity of demand with changes in the number of varieties, there may be industry level economies of scale (see Brown (1991) and Lancaster (1984)).

16. In Ethier's model, average costs are decreasing in the number of available varieties of differentiated intermediate goods. Under frictionless trade, costs are the same everywhere because firms in each country have access to the world total of varieties. With trade costs (whether tariffs or transport costs), firms in larger countries will have cheaper access to a wider range of intermediates, and hence lower costs, than firms in smaller countries.

17. Convergence of industry level productivity is a central concern of Dollar and Wolff (1993) and Bernard and Jones (1996a and 1996b). These authors use overall GDP price levels to deflate sectoral outputs, so their results should be interpreted with caution for the reasons mentioned in the Introduction.

18. The null hypothesis of groupwise homoskedasticity is $\sigma_{\mathrm{cj}}^{2}=\sigma^{2}$. A Lagrange Multiplier test of this null can be performed by regressing squared residuals from the OLS regression of (14) on a 
vector of $K$ dummy variables $d_{i j}$, where $d_{i j}=1$ for country i and industry $j$; the number of observations from this regression times the regression $\mathrm{R}^{2}$ is a chi-squared statistic with $\mathrm{K}$ degrees of freedom. The value of this test statistic indicates rejection of the null at greater than the 0.01 level of significance.

19. Industry intercepts and constants are suppressed for readability.

20. See Leamer, 1978, pg. 112-114 for derivation and discussion of the formulas used here.

21 . The differences are jointly statistically significant at greater than the $.1 \%$ level of confidence. 